\title{
An Examination of Job Satisfaction of Bank Managers According to Extrinsic, Intrinsic, and General Motivational Factors (A Study of Dera Ghazi Khan Division)
}

\author{
Ansar Abbas, Irfan Ahmed Khan, Ahmed Din, Muhammad Shazaib* \\ Faculty Of Management Sciences, Department Of Commerce, Shah Abdul Latif University Khairpur Mirs \\ *Department of public administration, BZU, Multan
}

\begin{abstract}
Job satisfaction can be defined in many ways, including extrinsic, intrinsic, and general motivation. Such job satisfaction is basically directed to different intrinsic and extrinsic factors that are motivators of employee attitude. Our population included all the branch managers of various banks in Punjab, but we collect data from city banks manager of dg khan. We visit all branches and personally meet with branch manager to given the accurate data about our research through questionnaire. We did factor analysis, Correlation Analysis and Regression Analysis by using statistical software. After doing all analysis we conclude that there is positive relationship between variables (Independent and dependent). Our research is helpful for branch managers and their top management, students and different researcher who are interesting in this field.
\end{abstract}

Keywords: Job Satisfaction; Intrinsic; Extrinsic; Motivational Factors

DOI: $10.7176 / \mathrm{EJBM} / 12-19-02$

Publication date:July $31^{\text {st }} 2020$

\section{Introduction}

Mostly bank managers say that they earn low income according to their services and work activities that they provide whole day in bank. Many bank managers told that if they achieve their target within time then the higher management just say very good, excellent or issue an excellence letter.

The measurement of a manager's job satisfaction has been considered an important way of workplace productivity(Frye 2012). Job satisfaction generally use as independent variable like as morale, turnover and the commitment of the organization( $\mathrm{Lu}$, Zhao et al. 2019). Job satisfaction is generally attributed to many extrinsic and intrinsic factors that are use as motivator of employee behavior. How the employee feel and judge about these many factors and how these factors influence their job and provide them jobs satisfaction.

Single traditional approaches to ensuring job satisfaction are not being innovative or alternative approaches are to be considered. However, the higher management concerns their investment in human capital. Practitioners and researchers both are agree that the cost of personnel existing is considerably less than the expenses must be incurred the advertising of a vacancy, filter through and various interview, select the accurate candidate for the job and give him/her training to meet the standard of the bank.

So the expenses for the selection, the time most important, and the total training process is important for vacant management position then for line level position. So the need exist for higher management of the banks to create the job satisfaction within their managers, determine how or what intrinsic and extrinsic factors serve as a motivating driver for their bank managers, and understand these factor play an important role for achieving their goals.

At the end the following question is basic research expletory inquiry.

What is the extent of the relationship between various intrinsic, extrinsic, and general motivational factors and overall job satisfaction of Bank managers.....?

\subsection{Gap}

The extrinsic and other motivational factors also impact on job satisfaction of any bank manager. A relationship between the job satisfaction and the extrinsic and motivational factors of a bank manager job.

\section{Literature review}

\subsection{Extrinsic, Intrinsic and General Motivational Factors}

Job satisfaction can be conceptualization in many of ways; these are including intrinsic, extrinsic and other general motivational satisfaction. Job satisfaction is emotional states that are resulting from the appraisal of one's job or job experience prepared by various extrinsic and extrinsic factors. Segmenting the job satisfaction with two ways one is check by itself and other is check itself compare with other managers to their intrinsic and extrinsic rewards(Al Kabir, Savar et al. 2019).

Extrinsic job satisfaction is emotional states that are associated with jobs that are handled or controlled by the organization(O'Donoghue 2000). Mostly these rewards refer to as a hygiene factors. These are external factors that 
are effect on the level of satisfaction or dissatisfaction experience by an employee(Kasten, van Osch et al. 2019). These specific extrinsic rewards are very important for a job to achieve its motivational potential and the only extrinsic rewards are not sufficient to determine the intrinsic motivation(Alnakhi, Segal et al. 2019). These extrinsic rewards are including job security, compensation, tenure, opportunity for promotion, and job safety.

Intrinsic motivation is an emotional tool that are used to designed for jobs duties and show the employees attitude towards job tasks. In other words the managers are motivated with other financial rewards, like as high self esteem and personal growth(Lee and Blanchard 2019). The levels of intrinsic motivation are experience by an employee and intrinsic job satisfaction is depending on employee and his/her job(Chuang, Yin et al. 2009). Intrinsic satisfaction means to fulfill the employee obtain performance the work and their experience the feeling of self-actualization(Cherniss and Kane 1987). These desire or fulfillment according to five level of Maslow's hierarchy of needs (1954) and these are may be include career opportunity, skill variety, skill utilization, task significant and feedback.

General satisfaction over all an employee job's satisfaction refers to aggregation factors that measure the general satisfaction(Bhuian and Islam 1996). Minnesota job satisfaction Questionnaire to calculate the overall job satisfaction of Bank managers and to extent the relationship between its intrinsic, extrinsic and general motivational factors.

\subsection{Measuring Job Satisfaction}

Many number of conceptual frameworks model of job satisfaction has develop the variety of method for measure the job satisfaction(Judge, Weiss et al. 2017), some researchers says that there is no best method to measure the job satisfaction( $\mathrm{Lu}$, Lu et al. 2016). Many investigations on job satisfaction relationship are typically unique skills rather than multi skills techniques of data analysis(Boamah, Laschinger et al. 2018). Single-item measure to the job satisfaction is preferable that are based overall job satisfaction items.

\subsection{Theory of Work Adjustment}

Theory of adjustment show or tell the discrepancy between what an employee want actual from the job and what he receive from the job actually(Leonard and Schimmel 2016), theory of adjustment is the concept between individual or work environment. This theory used for work personality and work environment for check the adjusted work outcomes, like as tenure and job satisfaction(Davies, Stoermer et al. 2019). Work environment create many organizational needs, the individual employee are also many needs like as recognition and fringe benefits. Work adjustment is the indicator both the satisfaction of individual who are work in the organization or individual's satisfaction where the job tenure can be predict(Dahling and Librizzi 2015).

\subsection{Conceptual framework}

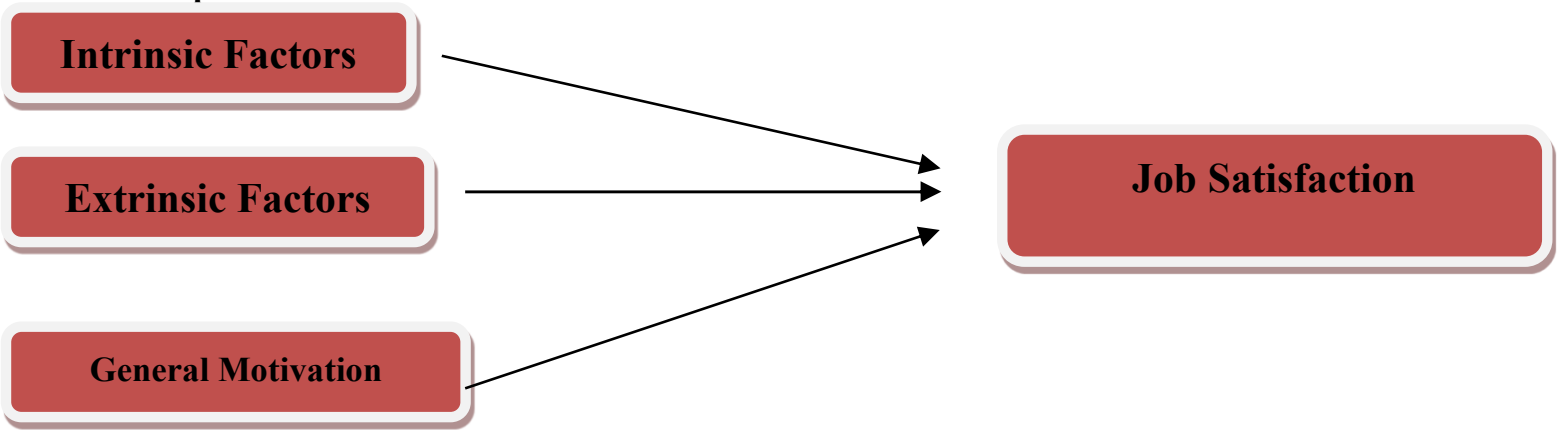

Independent Variables

Dependent Variable

Fig 1: Conceptual frame work

\subsection{Hypothesis}

H1. There is positive relationship between intrinsic motivational factors and job satisfaction

$\mathrm{H} 2$. There is positive relationship between extrinsic motivational factors and job satisfaction

H3. There is positive relationship between general motivational factors and job satisfaction

\subsection{Minnesota Satisfaction Questionnaire}

The Minnesota studies better known as work adjustment project was prepare of the Minnesota Satisfaction Questionnaire (MSQ). These MCQ's developed by Weiss, Dawis, England, and Lofquist (1967), a survey to know what is the assess of an employee job satisfaction. This technique use to measure the satisfaction of individual at work or work environment. This MSQ method is very useful for measure the satisfaction of individual because two individual may show the same common satisfaction but completely on different reasons. An individual has 
different needs and wants among the others those are work in same organization or other organizations. Understanding the workers needs and wants is the responsibilities of the higher management or operation management(Weiss, Dawis et al. 1967).

\section{Methodology}

\subsection{Research Objectives}

For this study our objective is how much relationship job satisfaction between intrinsic, extrinsic and other general motivational factors and how much effect these factors on a bank manager's job.

\subsection{Population \& Sampling}

Design answer the question by this research by using Weiss, Dawis, England, and Lofquist'sMinnesota Satisfaction Questionnaire (1967), many extrinsic and intrinsic items are include to measure the job satisfaction of bank managers. The questionnaire design for bank managers those who are work or provide their services national level in Pakistan especially in Dera Ghazi Khan Division. In this study we target the bank managers in Dera Ghazi Khan Division what they think about their job and their return in shape of rewards (intrinsic, extrinsic and general rewards). Questionnaire survey conducts and distribute among 156 bank managers in Dera Ghazi Khan Division in which include (Punjab Bank, Habib Bank, Allied Bank, MCB, Bank Islami, Soneri Bank, NBP, Meezan Bank, KASB, JS Bank, Tameer Bank, Silk Bank, Faisal Bank, Askari Bank, Sind Bank, Meezan Bank and UBL).

\subsection{Questionnaire}

This research is for the current time period and the data collect for the study is mostly primary data. For this study we adopt Minnesota satisfaction questionnaire by using 5 point lickert scale $1=$ Very Dissatisfaction, 2= Dissatisfaction, $3=$ Neutral, $4=$ Satisfaction and 5= Very Satisfaction.

The survey instrument that we adopt questionnaire for this research and to target the bank managers according to their Gender, Age, Monthly Income, Working hours, Experience about current job. These questionnaires measure the satisfaction or dissatisfaction of the manager's job with compare intrinsic, extrinsic and other general factors. For this we adopt Minnesota Satisfaction Questionnaire because in which use high degree of reliability to assess the intrinsic, extrinsic and general factors with job satisfaction.

\section{Results and Discussions}

\subsection{Reliability Analysis}

According to Nunnally (1987), if the value of Cronbach's alpha is greater than 0.7 then the instrument will be reliable. The table depicted that the value of cronbach's alpha of all variables greater than 0.7 , so the instrument is reliable. (Leech, Barrett, \& Morgan, 2004). The validity of questionnaire is checked by educational experts.

\section{Table 1: Inter item consistency-Cronbach alpha}

\begin{tabular}{lcc}
\hline Variable name & Cronbach's Alpha & No of Items \\
\hline Intrinsic Factors & 0.783 & 5 \\
Extrinsic Factors & 0.746 & 5 \\
General Motivational Factors & 0.801 & 5 \\
Job Satisfaction & 0.794 & 5 \\
\hline
\end{tabular}

\subsection{Demographic Analysis}

\section{Table2: Gender}

\begin{tabular}{|c|c|c|c|c|c|}
\hline & & Frequency & Percent & Valid Percent & Cumulative Percent \\
\hline \multirow{3}{*}{ Valid } & Male & 150 & 96.2 & 96.2 & 96.2 \\
\hline & Female & 6 & 3.8 & 3.8 & 100.0 \\
\hline & Total & 156 & 100.0 & 100.0 & \\
\hline
\end{tabular}

Table3: Age

\begin{tabular}{|c|c|c|c|c|c|}
\hline \multicolumn{6}{|c|}{0} \\
\hline & & Frequency & Percent & Valid Percent & Cumulative Percent \\
\hline \multirow{5}{*}{ Valid } & $25-30$ & 42 & 26.9 & 26.9 & 26.9 \\
\hline & $36-45$ & 30 & 19.2 & 19.2 & 46.1 \\
\hline & $46-50$ & 60 & 38.5 & 38.5 & 84.6 \\
\hline & above 51 & 24 & 15.4 & 15.4 & 100.0 \\
\hline & Total & 156 & 100.0 & 100.0 & \\
\hline
\end{tabular}




\begin{tabular}{rlrrrr}
\hline \multicolumn{5}{c}{ Table4: Experience } \\
\hline \multirow{4}{*}{ Valid } & Frequency & \multicolumn{2}{c}{ Percent } & Valid Percent & Cumulative Percent \\
\hline & $1-5$ & 42 & 26.9 & 26.9 & 26.9 \\
& $6-10$ & 30 & 19.2 & 19.2 & 46.1 \\
& $11-15$ & 30 & 19.2 & 19.2 & 65.3 \\
& above 16 & 54 & 34.7 & 34.7 & 100.0 \\
& Total & 156 & 100.0 & 100.0 & \\
\hline
\end{tabular}

Table5: Working Hours

\begin{tabular}{rlrrrr}
\hline & \multicolumn{2}{c}{ Frequency } & Percent & Valid Percent & Cumulative Percent \\
\hline \multirow{4}{*}{ Valid } & $5-7$ & 6 & 3.8 & 3.8 & 3.8 \\
& $8-10$ & 90 & 57.7 & 57.7 & 61.5 \\
& $11-13$ & 60 & 38.5 & 38.5 & 100.0 \\
& Total & 156 & 100.0 & 100.0 & \\
\hline
\end{tabular}

Table6: Monthly Income

\begin{tabular}{rlrrrr}
\hline & \multicolumn{2}{c}{ Frequency } & Percent & Valid Percent & Cumulative Percent \\
\hline \multirow{4}{*}{ Valid } & $40-50$ & 18 & 11.5 & 11.5 & 11.5 \\
& $51-60$ & 12 & 7.7 & 7.7 & 19.2 \\
& 61-70 & 24 & 15.4 & 15.4 & 34.6 \\
& above 71 & 102 & 65.4 & 65.4 & 100.0 \\
& Total & 156 & 100.0 & 100.0 & \\
\hline
\end{tabular}

Frequency distribution tests have been used, to analyze the demographic features of data like Gender, Age, Experience, Working Hours and Monthly Income. The result of frequency distribution depicted that most of the respondents are male. The individuals aged 46-50 years showed highest overall response rate is of 38.5 percent. The individual highest overall response in experience above 16 and the response is 34 percent. The individuals highest overall response in working hours is $8-10$ and the response is 57.7 percent and monthly income is above 71 and response rate is 65.4 percent.

\subsection{Descriptive Statistics}

Table7: Descriptive Statistics

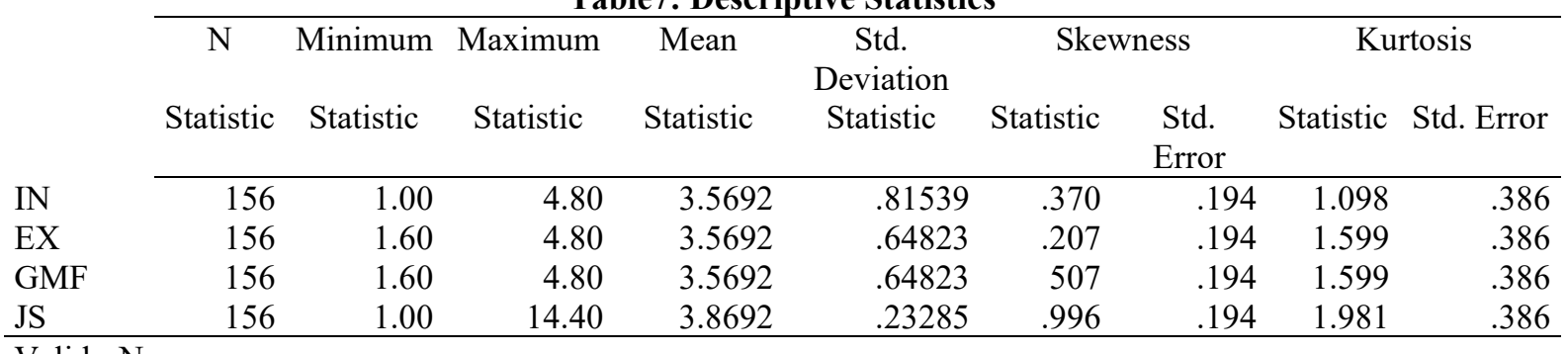

$\begin{array}{ll}\text { Valid N } & 156 \\ \text { (listwise) }\end{array}$

$\mathrm{N}=156$

Descriptive statistics explained the trend and level of existence of variables. The minimum and maximum showed the correctness of data and it should be in limits of measurement scale of instruments. As shown above, the maximum and minimum values are in the range from 1 to 5 likert scale. No value is less than 1 and no value above then 5 for all the independent and dependent variables. The mean of two variables is greater than 3 that mean all the average of responses lies in the agreement area the values of skewness should range from -1 to +1 while kurtosis should range from -3 to +3 and this is acceptable range(Sekaran $\&$ Bougie 2003). It is evident that all the statistics of skweness and kurtosis is within the acceptable range. So data collected for this study is normal this is also first and foremost assumption of regression analysis. 
Table8: Correlations

\begin{tabular}{|c|c|c|c|c|c|}
\hline & & IN & EX & GMF & JS \\
\hline & Pearson Correlation & 1 & & & \\
\hline \multirow[t]{3}{*}{ IN } & Sig. (2-tailed) & & & & \\
\hline & $\mathrm{N}$ & 156 & & & \\
\hline & Pearson Correlation & $.499^{* *}$ & 1 & & \\
\hline \multirow[t]{3}{*}{ EX } & Sig. (2-tailed) & & & & \\
\hline & $\mathrm{N}$ & 156 & 156 & & \\
\hline & Pearson Correlation & $.499^{* *}$ & $1.000^{* *}$ & 1 & ** \\
\hline \multirow[t]{3}{*}{ GMF } & Sig. (2-tailed) & & & & \\
\hline & $\mathrm{N}$ & 156 & 156 & 156 & 156 \\
\hline & Pearson Correlation & $.368^{*}$ & $.332^{* *}$ & $.332^{* *}$ & 1 \\
\hline \multirow[t]{2}{*}{ JS } & Sig. (2-tailed) & .036 & & & \\
\hline & $\mathrm{N}$ & 156 & 156 & 156 & 156 \\
\hline
\end{tabular}

**. Correlation is significant at the 0.01 level (2-tailed).

*. Correlation is significant at the 0.05 level (2-tailed).

The correlation between the independent variables (Intrinsic, Extrinsic and General Motivational Factors) and dependent variable (Job satisfaction). If the value of Pearson correlation coefficient is between -0.3 to +0.3 then there exists a weak relationship between the variables. If the value of Pearson correlation coefficient range is 0.3-0.7 then there exists a moderate relationship. And above 0.7 shows strong relationship between variables. (Leech, Barrett, \& Morgan, 2004)Advertising have positive relationship with consumer purchase intention.

\subsection{Regression Analysis}

Table9: Variables Entered/Removed ${ }^{\mathrm{a}}$

\begin{tabular}{lccc}
\hline Model & $\begin{array}{c}\text { Variables } \\
\text { Entered }\end{array}$ & $\begin{array}{c}\text { Variables } \\
\text { Removed }\end{array}$ & Method \\
\hline 1 & GMF, IN & & . Enter \\
\hline
\end{tabular}

a. Dependent Variable: JS

b. Tolerance $=.000$ limits reached.

Table10: Model Summary ${ }^{b}$

\begin{tabular}{lrrrrr}
\hline Model & R & R Square & $\begin{array}{c}\text { Adjusted R } \\
\text { Square }\end{array}$ & $\begin{array}{c}\text { Std. Error of the } \\
\text { Estimate }\end{array}$ & Durbin-Watson \\
\hline 1 & $.332^{\mathrm{a}}$ & .110 & .099 & .31989 & 1.961 \\
\hline
\end{tabular}

a. Predictors: (Constant), GMF, IN

b. Dependent Variable: JS

Table11: ANOVA ${ }^{\mathrm{a}}$

\begin{tabular}{rlrrrrr}
\hline Model & & Sum of Squares & df & Mean Square & F & Sig. \\
\hline \multirow{2}{*}{1} & Regression & 5.202 & 2 & 42.601 & 9.480 & $.000^{\mathrm{b}}$ \\
& Residual & 67.570 & 154 & 4.494 & & \\
& Total & 72.772 & 156 & & & \\
\hline
\end{tabular}

a. Dependent Variable: JS

b. Predictors: (Constant), GMF, IN

Table:12 Residuals Statistics ${ }^{\mathrm{a}}$

\begin{tabular}{lrrrrr}
\hline & \multicolumn{1}{c}{ Minimum } & \multicolumn{1}{c}{ Maximum } & \multicolumn{1}{c}{ Mean } & \multicolumn{1}{c}{ Std. Deviation } & $\mathrm{N}$ \\
\hline Predicted Value & 1.6066 & 5.2789 & 3.8692 & .74141 & 156 \\
Residual & -1.98624 & 10.03996 & .00000 & .10617 & 156 \\
\hline Std. Predicted Value & -2.052 & 1.901 & .000 & 1.000 & 156 \\
Std. Residual & -.937 & 4.736 & .000 & .994 & 156 \\
\hline
\end{tabular}

a. Dependent Variable: JS

The regression analysis showed the value of Durbin Watson is in the range. So no problem of serial correlation. The $\mathrm{R}$ showed the multiple correlation coefficients. It is the combined correlation of independent variable and dependent variable. $\mathrm{R}^{2}$ is the explanatory power of the model. It depicted the explained variation in Dependent variable due to independent variable. It explained the variation for sample and adjusted $\mathrm{R}$ square showed the variation for population.

Beta is the slope of relationship. However significant value of the variable (Intrinsic, Extrinsic and General Motivational Factors) is less than 0.05 , so the relationship between the Intrinsic, Extrinsic and General 
Motivational Factor and job satisfaction intention is significant. At the same time, the $t$ value is more than 2 , so a hypothesis is accepted.

\subsection{Hypotheses Result Summary}

Table12: Hypotheses summary

\begin{tabular}{lll}
\hline \multicolumn{1}{c}{ Hypotheses } & \multicolumn{1}{c}{ Statement of hypotheses } & Result \\
\hline Hypothesis 1 (H1) & There is positive relationship between intrinsic motivational & Accepted \\
Hypothesis 2 (H2) & factors and job satisfaction & Accepted \\
Hypothesis 3 (H3) & $\begin{array}{l}\text { There is positive relationship between extrinsic motivational } \\
\text { factors and job satisfaction }\end{array}$ & Accepted \\
& $\begin{array}{l}\text { There is positive relationship between general motivational factors } \\
\text { and job satisfaction }\end{array}$ & \\
\hline
\end{tabular}

\subsection{General Discussion}

There is a positive relationship between the intrinsic factors and job satisfaction of a bank manager because the internal desires of a bank manager is to utilize its unique skill for its branch and gain maximum benefits. Intrinsic factors direct effect on the job satisfaction, there is also positive relationship between the extrinsic factors and job satisfaction of a bank manager because the external needs and desires of a bank manager is to money and awards etc are also direct effect on the job satisfaction and other motivational factors also directly effect on the bank manager's job to fulfill their satisfaction.

\section{Conclusion}

There is positive relationship between the variables. Mostly branch managers know the relationship and the importance of these factors so they do work hard and achieve their targets within time because they know if they achieve target they get extra awards and the higher management become happy with them and as well as they are satisfied internally with their working.

\section{Practical Implication}

This study is helpful for bank managers to understand the intrinsic and extrinsic factors and make better and better their performance in the branch, this study is also helpful for higher management to understand the actual desire of their branch managers, this study is helpful for researchers who may want to research in this field and also helpful for student who may also done the research in this field or use for better guideline.

\section{Limitations}

The sample of population is use in this research is the bank managers in Dera Ghazi Khan and this research is only for the bank managers in specific current time period. This research is for the Dera Ghazi Khan Division.

\section{Future Research Direction}

It is opportunities for new people who want to research in this topic at any other place

\section{References}

Al Kabir, M. A., et al. (2019). "Effects of Work Life Balance on Employee Loyalty in Private Commercial Banks of Bangladesh."

Alnakhi, W. K., et al. (2019). "Motivational factors for choosing treatment destinations among the patients treated overseas from the United Arab Emirates: results from the knowledge, attitudes and perceptions survey 2012." Tropical diseases, travel medicine and vaccines 5(1): 18 .

Bhuian, S. N. and M. S. Islam (1996). "Continuance commitment and extrinsic job satisfaction among a novel multicultural expatriate workforce." The Mid-Atlantic Journal of Business 32(1): 35.

Boamah, S. A., et al. (2018). "Effect of transformational leadership on job satisfaction and patient safety outcomes." Nursing outlook 66(2): 180-189.

Cherniss, C. and J. S. Kane (1987). "Public sector professionals: Job characteristics, satisfaction, and aspirations for intrinsic fulfillment through work." Human Relations 40(3): 125-136.

Chuang, N. K., et al. (2009). "Intrinsic and extrinsic factors impacting casino hotel chefs' job satisfaction." International Journal of Contemporary Hospitality Management.

Dahling, J. J. and U. A. Librizzi (2015). "Integrating the theory of work adjustment and attachment theory to predict job turnover intentions." Journal of Career Development 42(3): 215-228.

Davies, S. E., et al. (2019). "When the going gets tough: the influence of expatriate resilience and perceived organizational inclusion climate on work adjustment and turnover intentions." The International Journal of Human Resource Management 30(8): 1393-1417. 
Frye, W. D. (2012). "An examination of job satisfaction of hotel front office managers according to extrinsic, intrinsic, and general motivational factors." International Journal of Business and Social Science 3(18).

Judge, T. A., et al. (2017). "Job attitudes, job satisfaction, and job affect: A century of continuity and of change." Journal of Applied Psychology 102(3): 356.

Kasten, S., et al. (2019). "The influence of pre-motivational factors on behavior via motivational factors: a test of the I-Change model." BMC psychology 7(1): 7.

Lee, H.-C. and M. R. Blanchard (2019). "Why teach with PBL? Motivational factors underlying middle and high school teachers' use of problem-based learning." Interdisciplinary Journal of Problem-Based Learning 13(1): 2.

Leonard, J. M. and C. J. Schimmel (2016). "Theory of Work Adjustment and Student-Athletes' Transition out of Sport." Journal of Issues in Intercollegiate Athletics 9.

Lu, H., et al. (2019). "Job satisfaction among hospital nurses: a literature review." International journal of nursing studies.

Lu, L., et al. (2016). "Work engagement, job satisfaction, and turnover intentions." International Journal of Contemporary Hospitality Management.

O'Donoghue, K. J. (2000). "Organisational Culture Receptiveness to Excellent Communication."

Weiss, D. J., et al. (1967). "Manual for the Minnesota satisfaction questionnaire." Minnesota studies in vocational rehabilitation. 